\title{
Prenatal care assessment according to the Prenatal and Birth Humanization Program
}

\author{
Maria Alice Tsunechiro 1 \\ Marlise de Oliveira Pimentel Lima 2 \\ Isabel Cristina Bonadio 3 \\ Marianne Dias Corrêa 4 \\ Amanda Villalba Alves da Silva 5 \\ Suzana Cristina Teixeira Donato 6
}

\begin{abstract}
1,3-6 Escola de Enfermagem. Universidade de São Paulo. Av. Dr. Enéas de Carvalho Aguiar, 419. CEP: 05.403-000. São Paulo, SP, Brasil. E-mail: tamnami@usp.br

2 Escola de Artes, Ciência e Humanidades. Universidade de São Paulo. São Paulo, SP, Brasil.
\end{abstract}

\begin{abstract}
Objectives: to analyze prenatal care process in primary health care units and compare the prenatal adequacy in the third trimester with maternal and perinatal outcomes.

Methods: a cross-sectional study of 2,404 pregnant women assisted in 2011in twelve primary health care units in the South region of São Paulo city. The data was collected through medical records. The assessment was based on the indicators process of the Programa de Humanização do Pré-natal e Nascimento (PHPN) (Prenatal and Birth Humanization Program). The prenatal adequacy in the third trimester was analyzed according to three criteria (early-onset, minimum of six consultations and puerperal consultation); and the compared maternal and perinatal outcomes were: type of childbirth, gestational age, birth weight and breastfeeding. The analysis was descriptive for the PHPN indicators and comparative for the prenatal adequacy by the chi-square test.

Results: early prenatal (82.9\%), minimum of six consultations (73.0\%) and puerperal consultation (77.9\%). In the overall of the PHPN indicators, there was an expressive decrease in the medical records (10.2\%). Prenatal care was adequate for $63.6 \%$ with a significant difference in relation to gestational age $(p=0.037)$ and birth weight $(p=0.001)$.

Conclusions: There were deficiencies in prenatal care. The difference between the groups in the perinatal outcomes reinforcing the need for prenatal care according to national indicators.

Key words Prenatal care, Health assessment, Quality indicators in health care, Women's health, Primary health care
\end{abstract}




\section{Introduction}

In Brazil, the maternal mortality rate is 64 women per 100,000 live births, three times higher than the World Health Organization (WHO) recommends, which is 20 per 100,000 . The reduction target for Brazil, according to the Objetivos de Desenvolvimento do Milênio (Millennium Development Goals) was to reach 35 deaths in 2015. Although there was a sharp decrease in the 1990s, but this goal was not achieved. ${ }^{1}$

In order to improve this indicator, a number of measurements have been taken by the Brazilian government, such as: increasing women's access to prenatal care, qualifying the actions developed and modifying the care model for childbirth.

The Programa de Humanização no Pré-Natal e Nascimento (PHPN) (Prenatal and Birth Humanization Program) emphasized the affirmation of women's rights proposing humanization as a strategy to improve the quality of care. ${ }^{2}$

In 2011, the so-called Rede Cegonha (RC) (Stork Network) was established with an aim to ensure women the right to reproductive planning, humanized pregnancy care, childbirth and puerperium, and child's right to safe birth, healthy growth and development up to 24 months of life, from four components: prenatal care, childbirth and birth, puerperium and essential child health care and logistic system (medical transport and regulation). ${ }^{3}$

In São Paulo city, in order to improve the quality in obstetric and neonatal care, in 2006 the Rede de Proteção à Mãe Paulistana (São Paulo Mother Protection Network) was created and incorporated into the RC in 2013. The Program aims to ensure: registration and link in the primary health care units for pregnant women near their homes; insertion of pregnant women exclusively through primary health care network, regularizing into the health system; linking pregnant women to a refe-rence hospital in their home area; means of transportation and free transportation pass so that the pregnant woman follows her prenatal at the health care unit in the city to make consultations, examinations and previously knows the hospital where she will give birth. ${ }^{4}$

In order to monitor the offered care, a computerized federal system, the Sisprenatal was available, for compulsory use and allows to evaluate prenatal and puerperal care based on the follow up of each pregnant woman. 5

The evaluation of prenatal care and in the puerperium is verified through the process of indicators previously defined results and impact, which must be continuously monitored.2,5
In a national level, two prenatal care assessment studies were conducted, one assessed the PHPN implementation and the another recently on a population-based study Nascer no Brasil, adopting some PHPN indicators.6,7 Other studies have been conducted reflecting in the real location, using two or more PHPN indicators. 8,9 However, there are few studies that assess the quality of prenatal care, considering all the process of the PHPN indicators, especially in regions of greater vulnerability.

Thus, the objectives of this study were to analyze the prenatal care process in 12 primary health care units in the South region in São Paulo city according to the process of the PHPN indicators, and comparing the prenatal care adequacy in the third trimester with maternal and perinatal outcomes.

\section{Methods}

This is a cross-sectional, retrospective study about the offering of prenatal care at primary health units in the district of Capão Redondo, in the South area in São Paulo city. The project was approved by the Research Ethics Committees at the Escola de Enfermagem da Universidade de São Paulo and the Secretaria Municipal de Saúde do Município de São Paulo under CAAE number: 08572012.3.0000.5392.

In 2011, in the district of Capão Redondo, a population of about 270,000 inhabitants presented an infant mortality rate of 12.4 per thousand live births and $10.0 \%$ of live births born with low birth weight. 10 In order to assist this population, the district counted on with 12 primary care health units, organized in 75 Estratégia Saúde da Família (ESF) (Family Health Strategy) teams and administered by a non-profit civil partnership organization. Each ESF team consisted of one physician, one nurse, two nursing assistants and six community health agents. The health staff at the time of the data collection was composed of 12 managers (nurses), 12 social workers and 12 technical-administrative assistants to assist pregnant women (one for each unit).Ten teams were incomplete, distributed in five primary health units, lacking professional physicians (there were 65 physicians). There were eight teams from the Núcleo de Atendimento à Saúde da Família (NASF) (Family Health Multidisciplinary Care) and 23 teams for oral health, divided into 12 primary health units.

Prenatal care offered by the ESF included consultations interspersed between the physician and the nurse, an active search for a community health agent, and that followed the established protocol by the city. The equipment and supplies were adequate, 
as recommended by the PHPN, and the area was appropriate to assist the pregnant woman.

The population of this study was composed of 2,891 pregnant women located from a report generated by the Sisprenatal database in 2011. 487 (16.8\%) pregnant women were excluded, seven of them were unconfirmed pregnancies, 218 were due to abortion, 16 did not attend the first prenatal care consultation and 246 had only done one prenatal consultation, but without any registration of gestational age and other data, making it impossible to analyze them. Thus, the final sample consisted of 2,404 pregnant women distributed throughout the 12 primary health units. The data was collected between December 2012 and May 2013.

The data was obtained from medical records composed of a prenatal care record used at the primary health unit, through a specific form by nurses and undergraduate nursing students. The data collection and registration were standardized by a guideline, in order to reduce bias and to obtain homogeneity in the collection. The data was stored in the Excel 2010 program (Microsoft Corporation), with double-entry typing for agreement assessment and error checking.

The criteria used in the prenatal and puerperal care process analysis, according to the PHPN process indicators were: 1) the beginning and up to 16 weeks of pregnancy; 2) minimum number of six consultations; 3) puerperal consultation; 4) the beginning and up to 16 weeks and minimum of six consultations; 5) the beginning and up to 16 weeks, minimum of six consultations and puerperal consultation; 6) the beginning and up to 16 weeks, minimum of six consultations and perform routine exams - blood typing $(\mathrm{ABO} / \mathrm{Rh})$ in the first consultation, syphilis (VDRL) in the first consultation and on the $30^{\text {th }}$ week, and anti-HIV in the first consultation, hemoglobin and hematocrit $(\mathrm{Hb} / \mathrm{Ht})$ in the first consultation, glycemia in the first consultation and on the $30^{\text {th }}$ week, urine test (AES - Abnormal Elements and Sediments in the urine) in the first consultation and on the 30th week; 7) the beginning and up to 16 weeks, minimum of six consultations, routine exams and puerperal consultation; 8) beginning up to 16 weeks, minimum of six visits, perform routine exams, puerperal consultation and immunization dose of tetanus vaccine; 9) immunizing dose of tetanus vaccine; 10) at least one consultation in the first trimester, two in the second and three in the third. 2

The achievement of the expanded PHPN indicators (inclusion of the clinical and obstetric procedures) expected for each trimester of gestation was also observed, all the criteria were considered to classify complete or incomplete prenatal care each trimester.

For the first trimester: a prenatal (PN) consultation, gestational age calculation, weight, gestational risk assessment, blood pressure measurement, folic acid prescription and tetanus immunization.

For the second trimester: beginning and up to 16 weeks, minimum of three PN consultations, gestational age calculation, weight, gestational risk assessment, blood pressure measurement, uterine height measurement, heartbeat auscultation, folic acid and ferrous sulfate prescription, first routine exams and tetanus immunization.

For the third: beginning and up to 16 weeks, minimum of six PN consultations, puerperal consultation, gestational age calculation, weight, gestational risk assessment, blood pressure measurement, uterine height measurement, heartbeat auscultation, folic acid and ferrous sulfate prescription, edema verification, guidance and encouragement for maternal breastfeeding, first and second routine exams and tetanus immunization.

All variables were categorized as performed or not, verified by the registration in the medical record as described as follows without analyzing the qualitative aspects of the PN care process.

Clinical and obstetric procedures were considered as performed when all the consultations were registered. For the first registration on uterine height and heartbeat rate, gestational ages were considered at $13^{\text {th }}$ and $14^{\text {th }}$ weeks, respectively. To assess the fetal presentation registration, the gestational age was considered at 28 weeks.

Laboratorial routine and imaging tests were considered carried out when the results were transcribed in the medical record.

Tetanus immunization was considered carried out when the pregnant woman had been immunized or had already received immunization.

The maternal and perinatal outcomes analyzed were the type of childbirth (normal/forceps and cesarean section), gestational age at birth $(\geq 37$ weeks and $<37$ weeks), birth weight ( $\geq 2500 \mathrm{~g}$ and $<2500 \mathrm{~g}$ ) and breastfeeding (yes or no).

The adequacy of the third trimester group to compare with the outcomes established by the attendance of three PHPN process indicators (the beginning and up to 16 weeks, minimum of six consultations and puerperal consultation).

The descriptive analysis of the variables was performed and the data were grouped into absolute and relative frequencies, central tendency measurements and dispersion. In order to compare the third- 
trimester PN adequacy group in relation to maternal and perinatal outcomes, the chi-square test was performed by the Statistical Package for Social Science 13.0 program and the level of significance used was $5 \%$.

\section{Results}

The mean age was $25.6(6.5)$ years old, with a variation between 11 and 45 years of age and 20.3\% (488) were adolescents. Most (60.4\%) were non-white, $59.1 \%(1,420)$ mixed and black; $1,662(69.1 \%)$ had 8 or more years of schooling, corresponding to at least a complete elementary schooling; 2,092 $(87.0 \%)$ were married or in a stable union and 1,186 $(49.3 \%)$ were employed.The average family income was R $\$ 1,366.57$ (R \$799.84), but there was a lack of information in $47.1 \%$ of the medical registrations analyzed. The proportion of primigravidas was $39.2 \%$ (943) and among those who had already given birth, the cesarean rate was $35.2 \%$.

The main results regarding the prenatal care process are presented in the data in Table 1. The mean gestational age at the onset of prenatal care was 11.4 (6.3) weeks and $73.7 \%$ started $\mathrm{PN}$ in the first trimester. The mean number of consultations was $7.6(3.3)$.
As there is an accumulative sum of the actions recommended by PHPN, there is a significant drop in the proportion of the registrations, especially referred to the routine exams.

In order to classify complete or incomplete PN by trimesters, the sample was separated by gestational age of prenatal termination/interruption in which $89(3.7 \%)$ were women who interrupted the PN up to 13 weeks, $212(8.8 \%)$ between 14 and 27 weeks and 2,103 (87.5\%) were complete between 28 and 42 weeks.

The PN in the first trimester was complete for 21 (23.6\%) women, who underwent prenatal care (PN) consultation, gestational age calculation, weight, gestational risk assessment, blood pressure measurement, folic acid prescription and tetanus immunization. Therefore, most of the women $(76.4 \%)$ assisted only in the first trimester did not registration of all the procedures expected for this stage.

The data referring to the second and third trimesters are presented in Table 2.

The classification of the gestational trimesters by the expanded PHPN showed a marked sequential decrease in the registrations of the procedures expected for each trimester from $23.6 \%$ to $12.3 \%$ and culminating in $4.2 \%$.

Of the 2,103 women who completed the PN in

Table 1

Assessment on the prenatal and puerperal care process, according to expanded PHPN indicators, São Paulo, Brazil, 2013.

\begin{tabular}{|c|c|c|}
\hline Prenatal and puerperal care & $\mathbf{N}$ & $\%$ \\
\hline Beginning and up to 16 weeks of gestation & 1,993 & 82.9 \\
\hline Minimum number of six prenatal consultations & 1,756 & 73.0 \\
\hline At least one visit on the 1 st trimester*, two on the $2^{\text {ndt }}$ and three in the $3^{\text {rd } \neq}$ & 1,160 & 48.3 \\
\hline Puerperal consultation & 1,872 & 77.9 \\
\hline Beginning and up to 16 weeks of gestation and at least six prenatal consultations & 1,579 & 65.7 \\
\hline $\begin{array}{l}\text { Beginning and up to } 16 \text { weeks of gestation, minimum of six prenatal consultations and } \\
\text { puerperal consultation }\end{array}$ & 1,348 & 56.1 \\
\hline Immunization dosage of tetanus vaccine & 1,648 & 68.6 \\
\hline $\begin{array}{l}\text { Beginning and up to } 16 \text { weeks of gestation, minimum of six prenatal consultations and } \\
\text { all the routine exams }\end{array}$ & 358 & 14.9 \\
\hline $\begin{array}{l}\text { Beginning and up to } 16 \text { weeks of gestation, minimum of six prenatal consultations, all } \\
\text { the routine exams and puerperal consultation }\end{array}$ & 316 & 13.1 \\
\hline $\begin{array}{l}\text { Beginning and up to } 16 \text { weeks gestation, minimum of six prenatal consultations, all the } \\
\text { routine exams, puerperal consultation, and the immunizing dose of the tetanus vaccine }\end{array}$ & 246 & 10.2 \\
\hline
\end{tabular}

*Up to 13 weeks; +14 to 27 weeks; $¥ \geq 28$ weeks. 
Classification of prenatal and puerperal care, according to the Prenatal and Birth Humanization Program (PHPN) indicators increased in the second and third gestational trimesters, São Paulo, Brazil, 2013.

\begin{tabular}{|c|c|c|c|c|c|c|c|c|}
\hline \multirow{3}{*}{ Procedures / Examinations } & \multicolumn{4}{|c|}{$2^{\text {nd }}$ Trimester $(n=212)$} & \multicolumn{4}{|c|}{ 3rd Trimester $(n=2103)$} \\
\hline & \multicolumn{2}{|c|}{ Complete } & \multicolumn{2}{|c|}{ Incomplete } & \multicolumn{2}{|c|}{ Complete } & \multicolumn{2}{|c|}{ Incomplete } \\
\hline & $\mathrm{n}$ & $\%$ & $\mathrm{n}$ & $\%$ & $\mathrm{n}$ & $\%$ & $\mathrm{n}$ & $\%$ \\
\hline Beginning of PN and up to 16 weeks & 174 & 82.1 & 38 & 17.9 & 1730 & 82.3 & 373 & 17.7 \\
\hline Number of consultations per trimester & 141 & 66.5 & 71 & 33.5 & 1740 & 82.7 & 363 & 17.3 \\
\hline Puerperal consultation & - & - & - & - & 1767 & 84.0 & 336 & 16.0 \\
\hline Immunity against tetanus & 120 & 56.6 & 92 & 43.4 & 1500 & 71.3 & 603 & 28.7 \\
\hline First routine exams & 125 & 59.0 & 87 & 41.0 & 1634 & 77.7 & 469 & 22.3 \\
\hline Blood typing / Rh Factor & 168 & 79.2 & 44 & 20.8 & 1960 & 93.2 & 143 & 6.8 \\
\hline VDRL* & 175 & 82.5 & 37 & 17.5 & 1915 & 91.1 & 188 & 8.9 \\
\hline HIV† & 160 & 75.5 & 52 & 24.5 & 1887 & 89.7 & 216 & 10.3 \\
\hline Hemoglobin / Hematocrit & 184 & 86.8 & 28 & 13.2 & 1940 & 92.2 & 163 & 7.8 \\
\hline $\mathrm{AES} \ddagger$ & 175 & 82.5 & 37 & 17.5 & 1940 & 92.2 & 163 & 7.8 \\
\hline Glycemia & 175 & 82.5 & 37 & 17.5 & 1940 & 92.2 & 163 & 7.8 \\
\hline According to routine exams & - & - & - & - & 493 & 23.4 & 1610 & 76.6 \\
\hline VDRL 30 & - & - & - & - & 1330 & 63.2 & 773 & 36.8 \\
\hline AES 30 & - & - & - & - & 662 & 31.5 & 1441 & 68.5 \\
\hline Glycemia 30 & - & - & - & - & 1422 & 67.6 & 681 & 32.4 \\
\hline Ultrasonography & 148 & 69.8 & 64 & 30.2 & 2016 & 95.9 & 87 & 4.1 \\
\hline Gestational age calculation & 201 & 94.8 & 11 & 5.2 & 2033 & 96.7 & 70 & 3.3 \\
\hline Weight & 193 & 91.0 & 19 & 9.0 & 1970 & 93.7 & 133 & 6.3 \\
\hline Blood pressure measurement & 196 & 92.5 & 16 & 7.5 & 1969 & 93.6 & 134 & 6.4 \\
\hline Gestational risk assessment & 160 & 75.5 & 52 & 24.5 & 1424 & 67.7 & 679 & 32.3 \\
\hline Body mass index & 31 & 14.6 & 181 & 85.4 & 202 & 9.6 & 1901 & 90.4 \\
\hline Nutrition chart & 6 & 2.8 & 206 & 97.2 & 49 & 2.3 & 2054 & 97.7 \\
\hline Measurement of uterine height & - & 77.4 & 48 & 22.6 & 1748 & 83.1 & 355 & 16.9 \\
\hline Uterine height chart & 8 & 3.8 & 202 & 96.2 & 53 & 2.5 & 2050 & 97.5 \\
\hline Fetal auscultation & 164 & 77.4 & 48 & 22.6 & 1781 & 84.7 & 322 & 15.3 \\
\hline Fetal presentation registration & - & - & - & - & 1566 & 74.5 & 537 & 25.5 \\
\hline Edema verification & - & - & - & - & 1528 & 72.7 & 575 & 27.3 \\
\hline Folic acid prescription & 144 & 67,9 & 68 & 32.1 & 1541 & 73,3 & 562 & 26.7 \\
\hline Ferrous sulfate prescription & 133 & 62,7 & 79 & 37.3 & 1595 & 75,8 & 508 & 24.2 \\
\hline Guidance on breastfeeding & 204 & 96,2 & 8 & 3.8 & 2057 & 97,8 & 46 & 2.2 \\
\hline Educational groups & 24 & 11,3 & 188 & 88.7 & 354 & 16,8 & 1749 & 83.2 \\
\hline PHPN extended by trimester§,॥ & 26 & 12.3 & 186 & 87.7 & 88 & 4.2 & 2015 & 95.8 \\
\hline
\end{tabular}

* VDRL: Venereal Disease Research Laboratory;

+ HIV: human immunodeficiency virus;

₹ AES: Abnormal elements and sediments in the urine;

§ 2nd trimester: beginning and up to 16 weeks, minimum of three PN consultations, gestational age calculation, weight, gestational risk assessment, blood pressure measurement, uterine height measurement, heartbeat auscultation, folic acid and ferrous sulfate prescription, first examinations and tetanus immunization.

"I 3rd trimester: beginning and up to 16 weeks, minimum of six PN consultations, puerperal consultation, gestational age calculation, weight, gestational risk assessment, blood pressure measurement, uterine height measurement, heartbeat auscultation, folic acid and ferrous sulfate prescription, edema verification, guidance and encouragement on breastfeeding, two rounds of routine examinations and tetanus immunization. 
Table 3

Maternal and perinatal outcomes, according to prenatal care adequacy in the 3rd trimester, São Paulo, Brazil, 2013.

\begin{tabular}{lccccccc}
\hline \multirow{2}{*}{ Outcome } & \multicolumn{2}{c}{ PN adequate } & \multicolumn{2}{c}{ PN inadequate } & \multicolumn{2}{c}{ Total } & \multirow{2}{*}{$\boldsymbol{p}^{*}$} \\
\cline { 2 - 6 } & $\mathrm{n}$ & $\%$ & $\mathrm{n}$ & $\%$ & $\mathrm{n}$ & $\%$ & \\
\hline Type of childbirth & & & & & & & 0.292 \\
$\quad$ Normal and forceps & 801 & 60.5 & 335 & 63.2 & 1136 & 61.3 & \\
$\quad$ Cesarean & 523 & 39.5 & 195 & 36.8 & 718 & 38.7 & \\
$\quad$ Gestational age at birth (weeks) & & & & & & & 0.036 \\
$\quad>37$ & 1104 & 93.5 & 419 & 90.3 & 1523 & 92.6 & \\
$\quad<37$ & 77 & 6.5 & 45 & 9.7 & 122 & 7.4 & \\
$\quad$ Weight at birth (g) & & & & & & & 0.001 \\
$\quad>2.500$ & 1215 & 93.0 & 455 & 88.0 & 1670 & 91.6 & \\
$\quad<2.500$ & 92 & 7.0 & 62 & 12.0 & 154 & 8.4 & \\
Breastfeeding & & & & & & & 1.000 \\
$\quad$ Yes & 1279 & 97.7 & 465 & 97.9 & 1744 & 97.8 & \\
$\quad$ No & 30 & 2.3 & 10 & 2.1 & 40 & 2.2 & \\
\hline
\end{tabular}

* Chi-square test.

the third trimester, $1,337(63.6 \%)$ were considered as having adequate $\mathrm{PN}$, according to the three indicators of the PHPN, in other words, initial gestational age up to 16 weeks, minimum of six consultations and puerperal consultation; and $766(36.4 \%)$ had inadequate PN. The appropriate PN group had better outcomes in relation to gestational age and birth weight (Table 3 ).

\section{Discussion}

The sample of pregnant women assisted at the health units revealed similarities with a population-based study Nascer no Brasil, young women, mostly mixed and/or black, schooling equivalent to complete elementary schooling, with a partner and about $40.0 \%$ of primigravidas. ${ }^{7}$ In this study, the context of the research site refers to women who were assisted in the PN in a public service with ESF in a region in São Paulo city, which does not configure the reality of the whole city or State.

In addition, the use of secondary data from the medical registrations can be considered a limiting factor in this study, since the lack of information registered does not necessarily mean that the actions were not performed. This fact is recurrent in studies based on the registrations. ${ }^{11,12}$ Despite this limitation, medical registrations have been used as an important source of data for scientific investigations. In the codes of professional ethics in health professionals, it is an ethical duty to register all the procedures performed with the patient. The Resolução de
Diretoria Colegiada $n^{\circ} 63$ de 2011 da Agência Nacional de Vigilância Sanitária (Board Resolution number 63 in 2011 of the National Health Surveillance Agency), which provides good practices in the health services, also providing in article 24 the responsibility for registering in medical records all the services provided by the health professionals. 13 In addition, these registrations are considered evidence in court procedures and health services audits.

In the general analysis of the results, it was observed that some actions presented a high frequency, but when the frequencies are added up, they descrease sharply.

The first PN consultation until the $4^{\text {th }}$ month of gestation and the minimum number of six consultations are essential actions for the PHPN. In this study, the adherence of pregnant women for PN care were generally satisfactory, since the average PN care beginning was precocious, and the mean number of consultations reached a higher number than recommended with similar results to a study performed in João Pessoa (Paraiba State) that obtained a mean of 11.27 (3.07) weeks of gestational age and a mean of consultations of 7.64 (1.59). ${ }^{14}$

However, the proportion of pregnant women who started prenatal care earlier was lower than some studies that varied from $83,6 \% 14$ and $93,0 \% 9$ and superior of others $(74,4 \% ; 1575,2 \% ; 375,8 \% 7)$.

The number of six or more consultations during prenatal care was lower than several recent studies that varied from $79,2 \% 15$ and $97,0 \% .9,16-18$ 
However, it was higher than the study conducted in Paraíba $(58,33 \%) .11$

The combination of early start of PN care and six consultations was similar to those found in two studies $\left(63,1 \% ; 869,0 \%{ }^{16}\right)$ and superior to another $(42,1 \%) .12$

The puerperal consultation is among the PN care quality criteria by PHPN. However, few studies analyze puerperal follow-up, an opportunity to assess the recovery of women in the postpartum period instituting the use of family planning methods and monitoring breastfeeding. Care for pregnant women should only be considered as completed after the puerperal consultation. ${ }^{6}$ In addition, the visit to the health unit for the puerperal consultation is also used in seeing the child, an important factor in the improvement of maternal and perinatal health indicators.

The national survey on women and children's demography and health (PNDS-2006) showed that only $39.0 \%$ of the births, woman performed the postpartum consultation, this is to show that this important stage of caring has been neglected in this country. 19 Other studies have shown higher percentages $\left(48,0 \%, 1958,2 \%\right.$ and $\left.62,2 \%{ }^{9}\right)$, however, lower than the present study $(77,9 \%)$

The proportion of test registrations found in the present study was higher than or similar to other studies with a decline between the first consultation and the repetition at the $30^{\text {th }}$ week.9,15-17,20 This result is great concern, since the exams provide information about the pregnant woman's health, it is important to screen for diseases that may have negative consequences in pregnant women and the concept, such as sexually transmitted infections such as syphilis, hepatitis B and HIV/AIDS, in addition to anemia, gestational diabetes, maternal-fetal blood incompatibility, asymptomatic gestational bacteriuria and toxoplasmosis. The repetition of some tests is indicated to control the remission of the disease or verification of its occurrence later in pregnancy.

The coverage of the HIV test $(89.7 \%)$ was superior to a national based study that found an $81 \%$ coverage among assessed pregnant women, having the possibility for improvement. 21

In Brazil, in 2013, 21,382 cases of syphilis were reported during the gestation with a rate of 7.4/1,000 live births (LB) and 13,705 new cases of congenital syphilis in children under one year of age indicating the rate of 4.7/1.000 LB.22 This is a clear marker of the quality in prenatal care, considering that the diagnosis and treatment can be effectively performed during the gestation in primary care services. Since in the third trimester, more than one-third of the pregnant women were not tested for syphilis, the quality of the PN care should be questioned.

In relation to the ultrasound examination is almost universally covered, although it is neither a mandatory examination nor a prenatal quality assessment criterion. This fact is repeated in several national studies, evidencing an inversion of values, since prenatal examinations and compulsory procedures have not presented the same coverage. $7,9,18$

It is also noted that the costs associated to this procedure are high. The National Health System/2017 Table of Procedures, Medications, Orthotics, Prostheses and Special Materials establishes a unit cost for obstetrical ultrasonography of $\mathrm{R} \$ 24.20$, while examinations such as Elements and abnormal sediments in the urine cost R $\$ 3.70$, glycemia dosage $\mathrm{R} \$ 1.85$, a complete blood test R\$ 4.11, non-treponemal test for syphilis detection $\mathrm{R} \$ 2,83.23$ Therefore, the cost of a single obstetrical ultrasound corresponds to almost the double of the sum in some of the required prenatal examinations.

Tetanus vaccination is considered an effective measurement in the prevention of neonatal tetanus. 5 A review study revealed low coverage by Sisprenatal $(45,78 \%)$ in Brazil and a higher proportion of vaccination coverage in surveys in different Brazilian cities $(75,81 \%) .24$ A study conducted in Espírito Santo State showed $58.7 \%$ of anti-tetanus vaccination. 16 In the present study, just over two-thirds $(68.6 \%)$ of the medical registrations, there was a registration of a pregnant woman who was immuned or vaccinated against tetanus. Efforts are needed to ensure coverage of tetanus immunization, not only to eradicate neonatal tetanus in the country, but also as a preventive measurement against tetanus in adult women. The opportunities to update the vaccination schedule should not be missed, hence during pregnancy, women seek the health service for prenatal control.

The analysis of the registered clinical-obstetric procedures showed that none of them did the proportion reaching the totality, having similar results as other studies. ${ }^{8-9,15}$ The actions related to the gestational age calculation, to measuring the blood pressure and weight, orientation on breastfeeding presented a frequency above $90 \%$ evidencing that such procedures are incorporated into the routine of the service. It should be emphasized that the performance and registration of the procedures are essential to assess the pertinence and adequacy of each of them throughout the gestation and to assess the correlation between them at each consultation.

The filling of nutritional and uterine height charts according to gestational age was extremely a 
faulty. This fact may suggest difficulty in adhering to the professionals' responsibility to consult, in case of the physician and nurse perform the registrationI on the charts due to perceived lack of value, or limited time for the prenatal consultation.It should be noted that these instruments, if properly completed, allow an accurate assessment and the orientation of the behavior, especially in cases of deviations from the normality.

The assessment of gestational risk in all the consultations is one of the basic conditions for effective prenatal care, which did not occur for approximately one-third of the pregnant women, both in the complete and incomplete PN groups. A higher value was observed in a recent study $(92,0 \%) .16$

Considering the early start of at least six consultations and the puerperal consultation, the adequacy of PN care reached little more than half of the women $(56,1 \%)$. When the analysis was broadened with the inclusion of all the routine exams recommended by the PHPN and tetanus immunization, this number decreased sharply to $10.2 \%$. In Brazil, the assessment of the early years of PHPN showed that when the whole routine of laboratorial tests, including anti-HIV was added, the adequacy was less than $5 \%$ in 2002.6 Thus, the results found in the present study show an evolution, corroborated by other similar studies, even though much lower than expected for a 10-year interval.7,15,16,24

A study conducted in the city of Aracaju, assessing the adequacy of the PN care by following the PHPN indicators: six or more consultations, firsttrimester start, clinical-obstetric procedures (weighing, blood pressure verification, uterine height measurement, breast palpation, gynecological examination), at least two blood tests performed (hemoglobin, hema-tocrit, fasting of glycemia, AES, HIV (one serology), and VDRL, the use of ferrous sulfate and a complete anti-tetanus vaccination scheme, showed that $\mathrm{PN}$ care was inadequate for $89.1 \%$ of the women, regardless to the type of PN care (public, private or mixed) and regardless to the family income. 25 In the present study, inadequacy PN care reached an even higher value of $95.8 \%$ when all the clinical and obstetrical procedures were added to PN during the three gestational trimesters. That is, only 88 women had all the procedures and examinations performed, according to the expanded PHPN criteria.

Therefore, the assessment of the quality of the PN care offered by the analyzed health units showed important flaws that need to be remedied in order to guarantee all pregnant women a PN care with the minimum of quality indicators established natio- nally.

The comparison in the third trimester showed a significant difference between the group of adequate and inadequate PN care in the perinatal outcomes related to gestational age and birth weight, confirming the importance of prenatal adjustment to the recommended minimum indicators. ${ }^{26}$

The birth of premature and low birth weight infants are important factors that contribute to infant morbidity and mortality with repercussions on the infant and lifelong development, as well as high cost for the Public Health System (SUS). ${ }^{27}$ In Brazil, the proportion of low birth weight for 2011 was $8.53 \% .28$ The total proportion of births with low birth weight in the study $(8.4 \%)$ was equivalent to the national data, but when we analyzed only the group of inadequate $\mathrm{PN}$, there was an increase of about $50.0 \%(12 \%)$. The data allowed us to infer that inadequate $\mathrm{PN}$ care increases the chances of preterm and low birth weight births, posing a challenge to be overcome by health professionals.

Considering that the proposal of the present study consisted in the normative assessment on PN care, in other words, the performance of the PN care procedures, the findings of this study are of a main concern because the study included health units organized by the ESF teams, since the premise of this modality in the public health service would be a facilitating condition for the adhesion of women for prenatal care. It was expected to find a higher proportion of compliance with the PHPN parameters at least for pregnant women who started prenatal care until 16 weeks of pregnancy. Studies show that ESF services have better levels of prenatal adequacy. 9,16

In this sense, it is understood that the PN assessment by the service must be a continuous process in the gestational period for each woman. For this to occur, it is suggested that managers establish checkpoints that serve as PN care indicators observing the attendance of the PHPN indicators and the Rede Cegonha (Stork Network) at the end of each gestational trimester,which would allow a more targeted active search in order to remedy the flaws found at that moment, reversing this situation before giving birth, which would give the PN care a higher quality and effectiveness and would favor more favorable maternal and child outcomes.

In conclusion, the data indicate that the PN care analyzed showed satisfactory results in isolation from the PHPN indicators, such as: early onset, number of prenatal consultations, examinations and puerperal consultation. However, when the indicators are checked together there is a marked decrease 
in the $\mathrm{PN}$ adequacy.

The performance of clinical and obstetrical procedures was also low, although some have reached high proportions. In addition, deficiencies in care were evidenced, such as failures in registering procedures, exams and tetanus immunization, thus compromising the quality and the assessment of PN offered.

There was a difference between the PN care adequacy groups regarding prematurity and low birth weight, reinforcing the importance of considering the minimal norms recommended by PHPN for the accomplishment of qualified and humanized care.

\section{References}

1. Instituto de Pesquisa Econômica Aplicada. Objetivos de Desenvolvimento do Milênio: Relatório Nacional de Acompanhamento/ Coordenação: Instituto de Pesquisa Econômica Aplicada e Secretaria de Planejamento e Investimentos Estratégicos; supervisão: Grupo Técnico para o acompanhamento dos ODM. - Brasília (DF): Ipea: MP, SPI; 2014.

2. Brasil. Ministério da Saúde. Portaria $n^{\circ} 569$, de 01 de junho de 2000. Institui o Programa de Humanização no Pré-natal e Nascimento, no âmbito do Sistema Único de Saúde. In: Diário Oficial da União, Brasília (DF); 8 de junho de 2000, seção 1, p.4-6.

3. Brasil. Ministério da Saúde. Secretaria de Atenção à Saúde. Departamento de Ações Programáticas Estratégicas Portaria $\mathrm{n}^{0} 1.459$, de 24 de junho de 2011. Institui no âmbito do Sistema Único de Saúde - SUS - a Rede Cegonha. Brasília (DF); 2011.

4. São Paulo (cidade). Secretaria Municipal de Saúde. Decreto $\mathrm{n}^{\circ}$ 46.966, de 02 de fevereiro de 2006. Regulamenta a Lei n. 13.211, de 13 de novembro de 2001, estruturando a Rede de Proteção à Mãe Paulistana, para a gestão e execução da rede de serviços de saúde de assistência obstétrica e neonatal no Município de São Paulo. Diário Oficial da Cidade de São Paulo, São Paulo, 3 de fevereiro de 2006, Seção 1, p.1.

5. Brasil. Ministério da Saúde. Secretaria de Atenção à Saúde. Departamento de Atenção Básica. Caderno de atenção básica $n^{\circ} 32$ : atenção ao pré-natal de baixo risco. Brasília; 2012.

6. Serruya SJ, Cecatti JG, Lago TG. O Programa de Humanização no Pré-natal e Nascimento do Ministério da Saúde no Brasil: resultados iniciais. Cad Saúde Pública. 2004; 20 (5): 1281-9.

7. Viellas EF, Domingues RMSM, Dias MAB, Gama SGN, Theme Filha MM, Costa JV, Bastos MH, Leal Mdo C. Prenatal care in Brazil. Cad Saúde Pública. 2014; 30 (Supl.): S85-S100.

8. Corrêa CRH, Bonadio IC, Tsunechiro MA. Normative prenatal evaluation at a philanthropic maternity hospital in São Paulo. Rev Esc Enferm. USP. 2011; 45 (6): 1293-1300.

\section{Acknowledgments}

The National Council for Scientific and Technological Development (CNPq) for funding the research project (Case $\mathrm{N}^{0} 485.264 / 2011-0$ ), from which the study data were extracted.

9. Oliveira RLA, Fonseca CRB, Carvalhaes MABL, Parada CMGL. Evaluation of pre-natal care from the perspective of different models in primary care. Rev Latino-Am Enferm. 2013; 21 (2): 546-53.

10. Observatório Cidadão Rede Nossa São Paulo. [acesso em 20 nov 2014]. Disponível em: http://www.nossasaopaulo. org.br/observatorio/regioes.php?regiao $=12 \&$ distrito $=19$.

11. Santos SMP, Santos LV, Rodrigues JO, Lira LCS, Souza LB, Silva UB. Accessibility to women's healthcare service during pregnancy and postpartum. Cogitare Enferm. [periódico online]. Jan/mar 2016 [acesso em 15 fev 2016]; 21 (1): 01-19. Disponível em: http://ojs.c3sl.ufpr.br/ ojs2/index.php/cogitare/article/view/42930/27514

12. Polgliani RBS, Santos Neto ET, Zandonade E. Informações dos cartões de gestantes e dos prontuários da atenção básica sobre assistência pré-natal. Rev Bras Ginecol Obstet. 2014; 36 (6): 269-75

13. Brasil. Ministério da Saúde. Agência Nacional de Vigilância Sanitária. Resolução de Diretoria Colegiada RDC n. 63, de 25 de novembro de 2011. Dispõe sobre os Requisitos de boas práticas de funcionamento para os serviços de saúde. Diário Oficial da União, Brasília (DF): 28 nov 2011, seção 1, p.44-46.

14. Silva EP, Lima RT, Ferreira NLS, Costa MJC. Pré-natal na atenção primária do Município de João Pessoa-PB: caracterização de serviços e usuárias. Rev Bras Saúde Matern Infant. 2013; 13 (1): 29-37.

15. Domingues RMSM, Hartz ZMA, Dias MAB, Leal MC. Avaliação da adequação da assistência pré-natal na rede SUS do Município do Rio de Janeiro, Brasil. Cad Saúde Pública. 2012; 28 (3): 425-37.

16. Martinelli KG, Santos Neto ET, Gama SGN, Oliveira AE. Adequação do processo de assistência pré-natal segundo os critérios do Programa de Humanização do Pré-natal e Nascimento e Rede Cegonha. Rev Bras Ginecol Obstet. 2014; 36 (2): 56-64.

17. Cesar JA, Sutil AT, Gabriela BS, Cunha CF, MendonzaSassi RAM. Assistência pré-natal nos serviços públicos de saúde: estudo transversal de base populacional em Rio 
Grande, Rio Grande do Sul, Brasil. Cad Saúde Pública 2012; 28 (11): 2106-14.

18. Vettore MV, Dias M, Vettore MV, Leal MC. Avaliação da qualidade da atenção pré-natal dentre gestantes com e sem história de prematuridade no Sistema Único de Saúde no Rio de Janeiro, Brasil. Rev Bras Saúde Matern Infant. 2013; 13 (2): 89-100

19. Brasil. Ministério da Saúde. Centro Brasileiro de Análise e Planejamento. Pesquisa nacional de demografia e saúde da mulher e da criança PNDS 2006 - relatório final. Brasília, DF; 2008.

20. Anversa ETR, Bastos GAN, Nunes LN, Pizzol TSD. Qualidade do processo da assistência pré-natal: unidades básicas de saúde e unidades de Estratégia Saúde da Família em município no Sul do Brasil. Cad Saúde Pública. 2012; 28 (4): 789-800

21. Domingues RM, Szwarcwald CL, Souza Júnior PR, Leal MC. Prenatal testing and prevalence of HIV infection during pregnancy: data from the "Birth in Brazil" study, a national hospital-based study. BMC Infect Dis. 2015; 15: 100 .

22. Brasil. Ministério da Saúde. Secretaria de Vigilância em Saúde. Departamento de DST, Aids e Hepatites Virais Boletim Epidemiológico - Sífilis 2015. Ano IV n.1 Brasília (DF): 2013.

23. Andreucci CB, Cecatti JG. Desempenho de indicadores de processo do Programa de Humanização do Pré-natal e Nascimento no Brasil: uma revisão sistemática. Cad Saúde Pública. 2011; 27 (6): 1053-64.

Received on December 07, 2017

Final version presented on May 31, 2018

Approved on September 21, 2018
24. Departamento de Informática do SUS (DATASUS). Sistema de Gerenciamento da Tabela de Procedimentos e Órtese, Próteses e Materiais Especiais do SUS. [acesso em 10 mai 2018]. Brasília (DF). Disponível em http://sigtap.datasus.gov.br/tabelaunificada/app/sec/procedimento/exibir/0202031110/05/2018

25. Carvalho RAS, Santos VS, Melo CM, Gurgel RQ, Oliveira CCC. Assessment of the adequacy of prenatal care according to family income in Aracaju, Sergipe State, Brazil, 2011. Epidemiol Serv Saúde. 2016; 25 (2): 271-80.

26. Ferraz TR, Neves ET. Fatores de risco para baixo peso ao nascer em maternidades públicas: um estudo transversal. Rev Gaúcha Enferm. 2011; 32 (1): 86-92.

27. Menezes LO, Pinheiro RT, Quevedo LA, Oliveira SS, Silva RA, Pinheiro KAT, et al. The impact of low birth weight related to gestational depression on federal funding of public health: a study in Pelotas, Rio Grande do Sul State, Brazil. Cad Saúde Pública. 2012; 28 (10): 1939-48.

28. Departamento de Informática do SUS (DATASUS). Indicadores e dados básicos Brasil 2012 Indicadores de fatores de risco e proteção Proporção de nascidos vivos de baixo peso ao nascer. [acesso em 20 jan. 2016] Brasília (DF). Disponível em http://tabnet.datasus.gov.br/ cgi/tabcgi.exe?idb2012/g16.def 